\title{
INSURANCE AND ECONOMIC DEVELOPMENT IN NIGERIA: CO-INTEGRATION AND CAUSALITY ANALYSIS
}

\author{
Mfon Sampson Ukpong \\ Department of Insurance, University of Uyo, Akwa Ibom State, Nigeria. \\ Ikechukwu A. Acha \\ Department of Banking/Finance, University of Uyo, Akwa Ibom State, Nigeria.
}

\begin{abstract}
We examine the cointegration and causal relationship between insurance and economic development in Nigeria using time series data from 1990 - 2013. Gross domestic product (GDP) is adopted as a proxy for the level of economic development, while total life insurance premiums (TPL), total non-life insurance premiums (TPNL) and total insurance investment (TII) are used in measuring growth in the insurance sector. Data is operationalized through the stationarity test, cointegration test, regression analysis and granger causality tests. The stationarity test reveals that all-time series data are stationary at the 1\%, 5\% and $10 \%$ levels of significance. The test for cointegration shows that all cointegrate when GDP is the endogenous variable. The granger causality test reveals that there is a bidirectional relationship existing between GDP and total non-life insurance premiums while a unidirectional relationship exists between GDP and total life insurance premiums with no causal relationship existing between GDP and total insurance investments. An R-squared value of 0.9776 indicates that the independent variables account for $97.8 \%$ of the variations in GDP while the remaining $2.2 \%$ is attributable to influence of other variables or fators not in the scope of this study. We conclude that insurance not only contributes to economic development but also has a long term equilibrium relationship. Therefore, we recommend that insurance activities in the country should be encouraged to promote effectiveness and efficiency in order to enhance the long term relationship with economic development.
\end{abstract}

\section{INTRODUCTION}

The Insurance Sector represents the backbone of Nigeria's risk management system. It ensures financial security, serves as an important component in the financial intermediation chain and offers a ready source of long term capital for infrastructural projects. Needless to say, the role of insurance in the growth and development of our economy cannot be overemphasized. To a certain extent, insurance mitigates the impact of risks and positively correlates with growth as entrepreneurs cover their exposures and inculcate more risk-taking abilities. In this regard, a strong and cooperative insurance industry is a compelling imperative for Nigeria's economic development and growth.

Ward and Zurbruegg (2000) are of the notion that insurance not only facilitates economic transactions through risk transfer and indemnification, but also promotes financial intermediation. Insurance is capable of promoting financial stability, mobilizing savings, facilitating trade and commerce and ensuring that risk is managed more efficiently with effective loss mitigation, efficient capital allocation and as a substitute and/or complement to government security programs (Ward and Zurbruegg, 2000; Skipper, 2001). In the 
words of Johnson (2008), a thriving insurance sector is not only the result of an efficient financial services sector but is also an important aspect of a healthy modern economy.

Insurance is designed to protect the financial wellbeing of an individual, company, other entity or society at large against unexpected loss (Oke, 2012). It is social in nature because it represents the cooperation of various individuals for mutual benefits by combining together to reduce the consequence of similar risks. As new areas of risk emerge with each passing day, there is need for new insurance packages to take care of more and more areas of risk, hence, insurance booms. Badejo (1998) in Eze and Okoye (2013) posits that the concept of insurance in its modern form was introduced into Nigeria by the British in the closing years of the $19^{\text {th }}$ Century with the establishments of trading posts by European trading companies. These companies effected their insurance with established insurers in the London Insurance market. Later on, some British Insurers appointed Nigerian agents to represent their interest in the country. These agents later metamorphosed into full branch offices of their parent companies in Britain.

Between 1958 when the first indigenous insurance company, the African Insurance Company Limited was established, until 2005, Nigeria had a total of one hundred and four (104) insurance companies and four (4) reinsurance companies. Insurance recapitalization was introduced by Section 9(4) of Insurance Act 2003 with a further recapitalization in 2005 which led to a capital base of N2billion for Life Insurance, N3billion for General Insurance (non-life) and N10billion for Reinsurance. This recapitalization was effected through mergers and acquisitions which results to the reduction of insurance and reinsurance companies from 104 to 49 , and from 4 to 2 respectively (Acha, 2007). However, the major developments of the insurance system include the promulgation of the Nigerian Insurance Decree, 1976; establishment of the National Insurance Commission (NAICOM)in 1997 and the 2003/2005 Insurance Recapitalizations. (Fatula, 2007; Eze and Okoye, 2013; Akpan and Acha,2011).

It is believed that the practice and the activities of the insurance sub-sector in Nigeria has played a crucial role in the development of the economy and in managing the risks of households and firms through the issuance of insurance policies coupled with the mobilization and transfer of funds to the deficit unit for financing real sector investment. Oke (2012), Shittu (2012) and Eze and Okoye (2013) opine that insurance companies affect economic growth by providing protection for the insured through the channels of marginal productivity of capital, technological innovation and savings rate. They believe that through this process, the insurance industry contributes to the growth of the Nigerian economy. While some literature suggest that financial intermediation promotes economic growth (Acha, 2011; Ekpenyong and Acha, 2011; Mojekwu, Agwuegbo and Olowokudejo, 2011; Shittu, 2012 and Oke, 2012), others like Wadlamanti, (2008) and Hao (2006) opine that financial intermediation does not affect economic growth. To this end, we embark on this study with the aim of filling the gap in the literature by making a co-integration and causality analysis of insurance and economic growth in Nigeria. This paper is organized as follows: Section One introduces the study. Section Two provides a literature review. In section three, we describe the variables used in our analysis such as insurance premiums and investments while at the same time reviewing some facts about the Nigerian economy. In section four, we carry out our co-integration and causality analysis and test the variables for existence of unit root. Thus, we establish a relationship between insurance and economic growth. Section five provides the summary and concluding remarks.

\section{CONCEPTUAL AND THEORETICAL FRAMEWORK}

Insurance can generally be defined as the pooling of funds from the insured (policy holders) in order to pay for relatively uncommon but severely devastating losses which can occur to the insured. It is a contract between two parties whereby one party called the insurer undertakes to pay the other party called the insured a fixed sum of money on the occurrence of a certain event. Obasi (2010) defines insurance as "a contract between the person who buys insurance and an insurance company who sold the policy". He opines that by entering into the contract, the insurance company agrees to pay the policyholder or his dependents a predetermined sum of money in any case of any unfortunate event for a predetermined fixed sum payable which is referred to as the premium. In Nigeria, the types of insurance products available include: fire, marine, aviation and transit, life covers, health, oil and gas insurances amongst others (Akpan and Acha, 2011). With the aid of these products, insurance provides stability by allowing large and small businesses operate with a lesser risk of volatility or failure; thus promoting the growth of large and small 
firms. By collecting premiums from insureds, insurers are able to pull together a large pool of funds that could be invested for short or long term periods. Such long-term funding in the economy is very critical for economic growth and the deepening/broadening of the domestic financial system (Acha and Ukpong, 2012; Obasi, 2010; Augustine and Nwanneka, 2011).

Theoretical and empirical studies have shown that countries with better developed financial system enjoy faster and more stable long-run growth. Well-developed financial markets enhanced by the operation of insurance companies tend to have a significant positive impact on total factor productivity, which translates into higher long run development (Oke, 2012). Based on Solow's (1956) work, Merton (2004) noted that due to the absence of a financial system that can provide the means of transforming technical innovation into broad implementation, technological progress will not have significant and substantial impact on the economic growth and development. This is as a follow up to the theory developed by Merton and Bodie (1995) referred to as the modern theory of financial intermediation. This theory emphasizes six core functions of insurance to include: provision of means for clearing and settling payments to facilitate exchange of goods and services; provision of mechanism for pooling resources; resource allocation; risk management; provision of price information to help in coordinating decentralized decision making in various sectors of the economy and provision of means to tackle the problem of moral hazard, physical hazard and information asymmetry. Thus their theory of financial intermediation encapsulates both the traditional financial theory and the changes in the financial environment. Eze and Okoye (2013) believe that it is by realizing these functions that the insurance sector contributes to economic growth. They opine that the channels to growth model links the financial intermediation function of insurance companies to economic growth; as well-developed financial intermediation is capable of promoting economic growth through marginal productivity of capital, efficiency of channelling savings to investment, savings rate and technological innovations (Acha, 2012).

\section{INSURANCE AND ECONOMIC GROWTH}

Over the years, the insurance sub-sector has witnessed some significant growth worldwide. According to Beck and Webb (2003), the share of this sector in the financial sector has been increasing as reflected in the volume of business of the insurers. Theoretically, the various channels through which insurance can positively impact economic growth include mobilization of domestic savings, efficient management of different risks, mitigation of losses, more efficient allocation of domestic capital and promotion of financial stability (Acha and Ukpong, 2012; Skipper, 2001; Beck and Webb, 2003; Akinolo, 2013). Ward and Zurbruegg (2000) and Kugler and Ofoghui (2005) assert that in offering risk transfer, indemnification for unexpected large losses, financial intermediary services and real services, insurance markets have had a significant productive impact within economies. For instance, insurance can help to promote strategic investments in productive assets by providing surety to investors and other contractual claimants (such as banks) to protect the value of their investments against unanticipated severe losses (Adams, Andersson, Anderson, and Lindmark, 2000).

Crothers (2004) contends that post-independence insurance (particularly marine insurance) was instrumental in the economic development of the slave-owning states of the US. For instance, the development of a domestic marine insurance market enabled the Southern US to provide cost-effective risk protection for their exports of agricultural and associated industrial products without recourse to Lloyds of London. This exemplifies that insurance helped to stimulate economic growth and sustain the regional slave-based economy up to the end of the Civil War in 1865. MacMinn (1987) in Adams et al (2000) reports that insurance can further provide an important post-loss financing function and mitigate agency problems such as the under-investment incentive that can occur in (particularly highly levered) companies that suffer a large asset loss. This leads to insurance having positive externalities in terms of employment creation, increased economic activity, business innovation and risk taking. In the same article, John (1953) in his analysis of economic contribution of insurance in the development of Britain's industrial revolution in the eighteenth century, points out that insurance companies were active suppliers of debt capital to entrepreneurs alongside the banks. 


\section{EMPIRICAL FRAMEWORK}

While several studies have attempted to identify the various ways through which insurance can affect economic growth, only few have addressed the issue of causality between insurance and economic growth. The available empirical evidence on this relationship has produced mixed results. Hence, while some studies such as Boon (2005), Arena (2008) and Webb et al (2002) found a unidirectional causality between insurance and economic growth, others like Ching, Kogid and Furuoka (2010) report the reverse. Still, others like Kugler and Ofoghi (2005) found evidence of a bidirectional relationship between insurance and economic growth while a handful provided evidence of neutrality between these two parameters. As an illustration, the study by Ward and Zurbruegg (2000) for OECD countries reported in Akinolo (2013) found no co-integration relationship for Austria, Switzerland, the UK and the US. For Australia, Canada, France, Italy and Japan, the null hypothesis of no co-integration relationship was rejected and the results also showed that insurance growth did cause economic growth for Canada, Italy and Japan. In a similar analysis, Catalan, Impavido and Musalem (2000) found no causality in many OECD countries and mixed results in emerging countries.

Peter and Kjell (2006) worked on the relationship between insurance and economic growth by applying a cross country panel data analysis using annual insurance premium data from 29 European countries over the 1992 to 2004 period. They observed a weak evidence for a growth-supporting role of life insurance and explained this with similarities to recent bank and stock sector findings. Arena (2008) worked on the empirical study and causal relationship between insurance market activity and economic growth which covers 56 countries (both developed and developing ones) in the period 1976 to 2004. He used the generalized method of moment for dynamic models of panel data and his results showed a positive and significant effect of total, life and non-life insurance market activity on economic growth. Haiss and Sumegi (2008) also applied a cross country panel data analysis from 29 European countries in the period 1992 to 2005 to study the relationship between insurance companies and economic growth in Europe. Using ordinary least squares estimates and time fixed effects, he observed that there is a positive impact of life insurance in GDP growth in 15 European countries; while general insurance has a larger impact in Central and Eastern Europe.

Wadlamannati (2008) examined the effects of insurance growth and reforms along other relevant control variables on economic development in India within the period 1980 to 2006. He used the penetration (life, general and total insurance) of insurance to measure the growth of insurance. Using ordinary least square, co-integration analysis and error correction models, the study showed that reforms in the insurance sector do not affect economic activities; but their growth has a positive impact on economic growth. Hao (2006) studied the relationship between financial intermediation and economic growth using specific data from China over the period 1985 to 1999 . The study employed a linear model and one-step parameter estimates for the Generalized Method of Moments (GMM). The study finds that bank as an indicator of financial development is significant and negatively related to growth. It further revealed that financial intermediation has a causal effect and positive impact on the growth channels of household's savings mobilization and substitution of loans for state budget appropriation. This was attributed to inefficiency in loan distribution and self-financing ability of the provincial government. Similarly, Eze and Okoye (2013) carried out an analysis of the effect of insurance practices on economic growth of the Nigerian Economy from 1980 to 2011. They employed unit root test, Johansen co-integration test and error correction model in data analysis and they observed that insurance premium capital has significantly impacted on economic growth. Also, the level of total insurance investment has significantly affected economic growth. Moreover, there is a causal relationship between insurance sector development and economic growth in Nigeria. They conclude that there is a significant positive effect of insurance practice on the growth of the Nigerian economy.

\section{METHODOLOGY}

This study is aimed at conducting a co-integration and causality analysis on insurance and economic growth in Nigeria. Dataspanning 1990 to 2013 are sourced from CBN Bureau of Statistics Database and NAICOM website. The model of Marijuana et al (2009) is applied in this study as modified by Oke (2012). He employs the model: 
$\mathrm{GDP}=\mathrm{f}(\mathrm{NIC}, \mathrm{PLI}, \mathrm{NLP}, \mathrm{TII}, \mathrm{INF}, \mu)$

Where GDP - gross domestic product, NIC - number of insurance companies in Nigeria, PLI - premium of life insurance companies; NLP - premium of non-life insurance companies, TII - total insurance investment and $\mu$ - disturbance term.

However, for this study, we shall limit our independent variables to total premiums of life insurance companies, total premiums of non-life insurance companies, and total insurance investments, while the GDP remains our dependent variable. It is believed that with these explanatory variables, we can successfully conduct a co-integration and causality test on insurance and economic growth in Nigeria.

In recognition of this fact, our model is thus presented as:

GDP = f $($ TPL, TPNL, TII + $\mu$ ) - $\ldots$

That is:

$\mathrm{GDP}=\mathrm{b}_{0}+\mathrm{b}_{1} \mathrm{TPL}+\mathrm{b}_{2} \mathrm{TPNL}+\mathrm{b}_{3} \mathrm{TII}+\mu \ldots \ldots . . \ldots \ldots$

This model is operationalized in a log-linear econometric construct to imbibe the coefficients of elasticity of the variables while lessening the probable effect that any outlier may have. Thus it is represented as:

$\operatorname{LogGDP}_{t}=b_{0}+b_{1} \operatorname{LogTPL}_{t}+b_{2} \operatorname{LogTPNL}_{t}+b_{3} \operatorname{LogTII}_{t}+\mu_{t}-\ldots-\ldots$

Where GDP - Gross Domestic Product, TPL - Total Life Insurance Premiums, TPNL - Total Non-life Insurance Premiums, TII - Total Insurance Investments, $\mu$ - disturbance term, $b_{0}$ - is a constant parameter; $b_{1}, b_{2}, b_{3}$ are explanatory variables and $t$ is the time trend. These are usually included in a standard time series specification to account for the omitted variables as well as unexplained random effects within the model.

Table 1: GDP at Current Prices, Total Life Insurance Premiums (TPL) Total Non-life Insurance Premiums (TPNL) and Total Insurance Investments (TII) in Nigeria 1990 - 2013. All figures are expressed in billions $(\mathrm{N})$

\begin{tabular}{|l|l|l|l|l|}
\hline Years & GDP & TPL & TPNL & TII \\
\hline 1990 & 472.6 & 0.0 & 1.013 & N/A \\
\hline 1991 & 545.7 & 0.0 & 1.296 & N/A \\
\hline 1992 & 875.3 & 0.0 & 2.445 & N/A \\
\hline 1993 & $1,098.7$ & 0.0 & 4.931 & N/A \\
\hline 1994 & $1,399.7$ & 0.0 & 14.519 & N/A \\
\hline 1995 & $2,907.4$ & 0.0 & 13.525 & N/A \\
\hline 1996 & $4,032.3$ & 0.0 & 11.091 & 12.379 \\
\hline 1997 & $4,189.2$ & 0.0 & 10.914 & 13.613 \\
\hline 1998 & $3,989.5$ & 0.0 & 11.688 & 15.656 \\
\hline 1999 & $4,679.2$ & 0.0 & 14.597 & 21.583 \\
\hline 2000 & $6,713.6$ & 0.0 & 22.531 & 25.192 \\
\hline 2001 & $6,895.2$ & 0.0 & 28.981 & 32.157 \\
\hline 2002 & $7,795.8$ & 0.0 & 37.765 & 36.940 \\
\hline 2003 & $9,913.5$ & 0.0 & 43.441 & 54.642 \\
\hline 2004 & $11,411.1$ & 0.0 & 50.100 & 74.590 \\
\hline 2005 & $14,610.9$ & 0.0 & 67.465 & 121.844 \\
\hline 2006 & $18,564.6$ & 0.0 & 81.583 & 216.359 \\
\hline 2007 & $20,657.3$ & 89.104 & 329.247 \\
\hline 2008 & $24,296.3$ & 16.274 & 126.470 & 336.491 \\
\hline 2009 & $24,794.2$ & 30.735 & 153.127 & 343.894 \\
\hline 2010 & $33,984.8$ & 36.833 & 157.336 & 351.459 \\
\hline 2011 & $37,409.9$ & 43.039 & 175.756 & 359.192 \\
\hline 2012 & $40,544.1$ & 57.996 & 258.402 & 364.231 \\
\hline 2013 & $42,396.8$ & 64.909 & 276.384 & 369.270 \\
\hline S & 80.520 & 2012 & \\
\hline
\end{tabular}

Source: CBN Annual Survey(2015) and NAICOM Annual Report (2012) 


\subsection{ANALYSIS OF RESULTS AND DISCUSSION OF FINDINGS}

\section{Test for Stationary}

In other to avoid the occurrence of spurious results, this study adopts the Augmented Dicker Fuller Test (ADF) in testing for the stationarity of the time series data. The ADF statistic tests for the persistence of shocks in a time series data as well as acts as a deterrent against spurious results. The ADF statistic outcome of the time series data for the period $1990-2013$ is as presented in the table below.

Table 2: Augmented Dickey-Fuller Test Statistic

\begin{tabular}{|l|l|l|l|l|l|}
\hline Variable & \multicolumn{4}{|l|}{ Critical Values } & \\
\hline & ADF & $1 \%$ level & $5 \%$ level & $10 \%$ level & Probability \\
\hline LogGDP & -0.568940 & -4.416345 & -3.622033 & -3.248592 & 0.9713 \\
\hline LogTPL & 1.490021 & -4.416345 & -3.622033 & -3.248592 & 0.9999 \\
\hline LogTPNL & 2.305256 & -4.571559 & -3.690814 & -3.286909 & 1.0000 \\
\hline LogTII & -2.361531 & -4.440739 & -3.632896 & -3.254671 & 0.3872 \\
\hline
\end{tabular}

Source:Authors computation using E-Views 8.0

The ADF test statistic outcome for the time series data for the period $1990-2013$ indicates that at $1 \%, 5 \%$ and $10 \%$ levels of significance, all time series data are stationary. This implies that the data is non spurious and possess a constant mean and varianace with a covariance that does not depend on time. Hence it can be recommended for future use as future statistical behaviour will be identical to past behaviour.

From, the table, $\log$ GDP has a t-statistic of -0.568940 which is less negative than the critical value, hence, we fail to reject the hypothesis that LogGDP has a unit root. Similarly, LogTPL, LogTPNL and LogTII also bear same characteristics, hence we draw same conclusion.

\section{Test for Cointegration}

Cointegration is used to test whether there is a long-run equilibrium relationship among the variables examined. The presence of a co-integrating vector would imply that an equilibrium relationship exists among the co-integrating variables, and that no matter the fluctuations in the short-run, the variables have a tendency to return to the equilibruim path in the long-run. Hence, given an initial disequilibrim, the cointegrating variables would not wander away from one vector endlessly but will eventually return to its equilibrium path (Johansen and Juselius, 1990).

For this study, the Johansen co-integration test is used.Although Johansen and Juselius (1990) are of the view that the maximum eigenvalue test may be better than the trace test, we use both tests. The trace statistics tests the null hypothesis that there are at most $r$ cointegrating relatinships. Hence, a rejection of the null hypothesis means that there are more than $\mathrm{r}$ cointegrating relationships (Okonkwo, Ogwuru and Ajudua, 2014). 
Table 3: Johansen Cointegration Test

\begin{tabular}{|c|c|c|c|c|}
\hline $\begin{array}{l}\text { Date: } 11 / 21 / 16 \\
\text { Sample (adjust } \\
\text { Included observ } \\
\text { Trend assumpti } \\
\text { Series: LOGGD } \\
\text { Lags interval (in }\end{array}$ & $\begin{array}{l}\text { me: } 12: 23 \\
: 324 \\
\text { ons: } 22 \text { after } \\
\text { : Linear dete } \\
\text { OGTII LOGT } \\
\text { st differences }\end{array}$ & $\begin{array}{l}\text { stments } \\
\text { istic trend ( } r e \\
\text { OGTPNL } \\
\text { to } 1\end{array}$ & ricted) & \\
\hline \multicolumn{5}{|c|}{ Unrestricted Cointegration Rank Test (Trace) } \\
\hline $\begin{array}{l}\text { Hypothesized } \\
\text { No. of CE(s) }\end{array}$ & Eigenvalue & $\begin{array}{l}\text { Trace } \\
\text { Statistic }\end{array}$ & $\begin{array}{c}0.05 \\
\text { Critical Value }\end{array}$ & Prob. ${ }^{* *}$ \\
\hline $\begin{array}{l}\text { None * } \\
\text { At most } 1^{*} \\
\text { At most } 2^{*} \\
\text { At most } 3^{*}\end{array}$ & $\begin{array}{l}0.976110 \\
0.834367 \\
0.751356 \\
0.461588\end{array}$ & $\begin{array}{l}165.9495 \\
83.79458 \\
44.23900 \\
13.62089\end{array}$ & $\begin{array}{l}63.87610 \\
42.91525 \\
25.87211 \\
12.51798\end{array}$ & $\begin{array}{l}0.0000 \\
0.0000 \\
0.0001 \\
0.0326\end{array}$ \\
\hline \multicolumn{5}{|c|}{$\begin{array}{l}\text { Trace test indicates } 4 \text { cointegrating eqn(s) at the } 0.05 \text { level } \\
{ }^{*} \text { denotes rejection of the hypothesis at the } 0.05 \text { level } \\
{ }^{* *} \text { MacKinnon-Haug-Michelis (1999) p-values }\end{array}$} \\
\hline $\begin{array}{l}\text { Hypothesized } \\
\text { No. of } \mathrm{CE}(\mathrm{s})\end{array}$ & Eigenvalue & $\begin{array}{l}\text { Max-Eigen } \\
\text { Statistic }\end{array}$ & $\begin{array}{c}0.05 \\
\text { Critical Value }\end{array}$ & Prob.* ${ }^{* *}$ \\
\hline $\begin{array}{l}\text { None * } \\
\text { At most } 1^{*} \\
\text { At most } 2^{*} \\
\text { At most } 3^{*}\end{array}$ & $\begin{array}{l}0.976110 \\
0.834367 \\
0.751356 \\
0.461588\end{array}$ & $\begin{array}{l}82.15493 \\
39.55558 \\
30.61811 \\
13.62089\end{array}$ & $\begin{array}{l}32.11832 \\
25.82321 \\
19.38704 \\
12.51798\end{array}$ & $\begin{array}{l}0.0000 \\
0.0004 \\
0.0008 \\
0.0326\end{array}$ \\
\hline \multicolumn{5}{|c|}{$\begin{array}{l}\text { Max-eigenvalue test indicates } 4 \text { cointegrating eqn(s) at the } 0.05 \text { level } \\
{ }^{*} \text { denotes rejection of the hypothesis at the } 0.05 \text { level } \\
{ }^{* *} \text { MacKinnon-Haug-Michelis (1999) p-values }\end{array}$} \\
\hline Unrestricted C & grating $\mathrm{Co}$ & its (norm & by $b^{\prime *} S 11^{*} b$ & \\
\hline
\end{tabular}

Source: Computer Output using E-views 8.0

From the table above, the trace statistic of $165.9495,83.79458,44.23900$ and 13.62089 clearly exceed the critical values of $63.87610,42.91525,25.87211$ and 12.51798 respectively at $95 \%$ confidence interval. Hence, we reject the null hypothesis and conclude that there is at most four cointergrating relationships, therfore, a long-run equilibrim relationship exist among the variables.

This claim is supported by the eigenvlaue test where the Max-eigen statistic of $82.15493,39.55558$, 30.61811 and 13.62089 also clearly exceed the critical values of $32.11832,25.82321,19.38704$ and 12.51798 at $5 \%$ significance level respectively. Hence, we reject the null hypothesis of no cointegration relationship among the variables. This implies there is a long-run relationship between GDP, total life insurance premiums and other variables.However, since cointegration does not provide information about possible patterns, the regression analysis and causality tests are carried out alongside. 


\section{REGRESSION ANALYSIS}

We conduct a multiple regression analysis to predict the relationship between the dependent variable (GDP) and the independent variables (TPL, TPNL and TII) as presented in Table 4.

Table 4: Regression Analysis

Dependent Variable: LOGGDP

Method: Least Squares

Date:11/21/16 Time: 14:03

Sample: 124

Included observations: 24

\begin{tabular}{lrlrr}
\hline \hline \multicolumn{1}{c}{ Variable } & Coefficient & Std. Error & t-Statistic & Prob. \\
\hline \hline C & 1833.839 & 730.5056 & 2.510369 & 0.0208 \\
LOGTII & 31.45031 & 7.529261 & 4.177078 & 0.0005 \\
\multicolumn{1}{c}{ LOGTPL } & -10.69578 & 68.36058 & -0.156461 & 0.8772 \\
\hline \hline & 112.9497 & 25.86229 & 4.367350 & 0.0003 \\
R-squared & 0.977646 & Mean dependent var & 13507.40 \\
Adjusted R-squared & 0.974293 & S.D. dependent var & 13630.68 \\
S.E. of regression & 2185.482 & Akaike info criterion & 18.36807 \\
Sum squared resid & 95526641 & Schwarz criterion & 18.56441 \\
Log likelihood & -216.4169 & Hannan-Quinn criter. & 18.42016 \\
F-statistic & 291.5606 & Durbin-Watson stat & 1.400128 \\
Prob(F-statistic) & 0.000000 & & & \\
\hline \hline
\end{tabular}

urce: Computer Output using E-views 8.0

From the table above, it can be observed that the probability value of 0.0208 is less than the critical value of 0.05 , hence the model is insignificant at $5 \%$ level of significance. However, LogTPL has a probability value of 0.8772 which is greater than the critical value implying that total life insurance premium is significant at 0.05 critical level. The results further demonstrate an overall positive effect of the regressors on the dependent variable. It can also be observed that a positive relationship exists between the GDP and TII as well as that of the GDP and TPNL. This is due to their positive coefficients of 31.45031 and 112.9497 respectively. On the other hand, with a coefficient of -10.69578 , total life insurance premiums exhibits a negative relationship with the GDP. This is in agrement with the works of Eze and Okoye (2013) that a positive relationship exist between total insurance investments and the gross domestic product.An Rsquared value of 0.977646 indicates that the independent variables account for $97.8 \%$ of the variations in GDP while the remaining $2.2 \%$ is attributable to influence of other variables or fators not included in the regression model.

The calculated Durbin Watson statistic is 1.400128. However, the tabulated Durbin Watson for lower limit $\left(\mathrm{d}_{\mathrm{L}}\right)$ and upper limit $\left(\mathrm{d}_{\mathrm{U}}\right)$ are 1.02 and 1.54 respectively. Since the calculated Durbin Watson falls within the limits of the tabulated Durbin Watson, we conclude that the test is inconclusive hence there may be autocollerations in the residuals. 


\section{GRANGER CAUSALITY TEST}

A Granger Causality test is used to determine whether there are bi-directional or uni-directional relationships among the variables. Okonkwo, Ogwuru and Ajudua (2014) opine that the Granger Causality test shows how much of the current $\mathrm{Y}$ can be explained by past values of $\mathrm{X}$ and whether adding lagged values of $\mathrm{X}$ can improve the explanation. A variable granger causes another if the F-statistic is significant at p-value of 0.05 or less.

Table 5: Granger Causality Test

Paifwise Granger Causality Tests

Date: 11/21/16 Time: 17:33

Sample: 124

Lags: 2

\begin{tabular}{|c|c|c|c|}
\hline Null Hypothesis: & Obs & F-Statistic & Prob. \\
\hline LOGTII does not Granger Cause LOGGDP & \multirow[t]{2}{*}{22} & 1.29557 & 0.2994 \\
\hline LOGGDP does not Granger Cause LOGTII & & 2.53196 & 0.1090 \\
\hline LOGTPL does not Granger Cause LOGGDP & \multirow[t]{2}{*}{22} & 0.91330 & 0.4200 \\
\hline LOGGDP does not Granger Cause LOGTPL & & 5.90119 & 0.0113 \\
\hline LOGTPNL does not Granger Cause LOGGDP & \multirow[t]{2}{*}{22} & 4.65623 & 0.0244 \\
\hline LOGGDP does not Granger Cause LOGTPNL & & 15.3571 & 0.0002 \\
\hline LOGTPL does not Granger Cause LOGTII & \multirow[t]{2}{*}{22} & 8.72929 & 0.0025 \\
\hline LOGTII does not Granger Cause LOGTPL & & 22.8364 & 2.E-05 \\
\hline LOGTPNL does not Granger Cause LOGTII & \multirow[t]{2}{*}{22} & 1.50152 & 0.2509 \\
\hline LOGTII does not Granger Cause LOGTPNL & & 0.27588 & 0.7622 \\
\hline LOGTPNL does not Granger Cause LOGTPL & \multirow[t]{2}{*}{22} & 6.28257 & 0.0091 \\
\hline LOGTPL does not Granger Cause LOGTPNL & & 5.72887 & 0.0125 \\
\hline
\end{tabular}

Source: Computer Output using E-views 8.0

Table 5 reveals that there are no causations between total insurance investments (TII) and gross domestic product (GDP). Same applies to total non-life insurance premiums (TPNL) and total insurance investments. A unidirectional causal relationship exists between gross domestic product and total life insurance premiums (TPL); while a bidirectional causal relationship exists between total non-life premiums and gross domestic product, total life premiums and total insurance investment; and total non-life premiums and total life premiums.

\section{CONCLUSION AND RECOMMENDATIONS}

This study delved into the causal relationship between insurance and economic development in Nigeria. Data covering the period $1990-2013$ was used for the analysis. The test for cointergration revealed the presence of four co integrating relationships. This implies that at there is a long run relationship between the gross domestic product, total life insurance premiums, total non-life premiums and total insurance investment. The regression analysis revealed that a positive relationship exists between total life insurance premiums, total non-life insurance premiums, total insurance investments and the gross domestic product, which serves as a proxy for economic development. This means that economic development is positively affected by insurance. The presence of a causal relationship with the GDP implies that insurance would contribute meaningfully to the development of the Nigerian economy. However, a unidirectional relationship exist between GDP and total life insurance premiums. This may be attributed to the low 
patronage of life insurance services in Nigeria which in turn may be due to low per capita income, lack of awareness, certain cultural beliefs and practices and unfavourable insurance regulatory framework.

From the findings made in the study, we recommend the following. First, insurance activities in the country should be encouraged and practitioners should aim at maximizing efficiency and effectiveness to better the long run relationship that exists between insurance and economic development. Second, adequate legislation and policy formulation as regards risk management and product innovation should be enforced. Third, the government should provide an appropriate environment that encourages insurance business. They should try to implement both monetary and fiscal policies that would reduce the rate of inflation in Nigeria. This will make more money available to the people and promote insurance.

\section{REFERENCES}

1. Acha, I. A. (2007). Consolidation in the Nigerian Insurance Industry: Issues and Challenges. Uyo Journal of Management Sciences, 2(1), 60 - 69.

2. Acha, I. A. (2011). Financial Intermediation by Banks and Economic Growth in Nigeria, 1990 2008, Journal of Economics and Sustainable Development, 2(4),129-139. Available online at www.iiste.org

3. Acha, I. A. (2012). Non-Bank Financial Institutions and Economic Development in Nigeria, International Journal of Finance and Accounting, 1(2): 14-22 DOI: 10.5923/j.ijfa.20120102.03

4. Acha, I. \&Ukpong, S. M. (2012). Micro-Insurance: A Veritable Product Diversification Option for Micro-Finance Institutions in Nigeria, Research Journal of Finance and Accounting,3(8), 78-85.

5. Adams, M., Andersson, J., Anderson, L. and Lindmark, M (2000) The Historical Relation between Banking, Insurance, and Economic Growth in Sweden: 1830 to 1998. Journal of Riskand Insurance 55 (2) 259-272.

6. Akpan, I. \& Acha, I. A. (2011). Principles of Insurance and Risk Management ( $2^{\text {nd }}$ ed.), Warsaw, Poland: SOWA Sp. z. o. o.

7. Anthony A. and Luke, O. (2011). The Effect of Insurance Business on Economic Development in Nigeria. Journal of Emerging Trends in Economics and management Sciences, 2(4): 275-280.

8. Arena, M. (2008). Does Insurance Market Activity Promote Economic Growth? A Cross- country Study of industrialized and Developing Countries, Journal of Risk and Insurance, 75, 921-946.

9. Augustine U. and Nwanneka J. (2011) Repositioning Insurance Industry for Operational Efficiency: The Nigerian Case. Journal of Applied Finance \& Banking, 1(3) 15-32.

10. Barro, R. and Sala-I-Martin, X. (1995). Economic Growth. New York: McGraw Hill, Inc.

11. Beck, T. and Webb, I. (2003). Economic, Demographic and Institutional Determinant of Life Insurance Consumption across Countries, World Bank and International Insurance Association.

12. Boon, T. (2005). Do Commercial Banks, Stock market and Insurance Market Promote Economic Growth? An analysis of the Singapore Economy, working paper of the school of Humanities and Social Studies, Nanyang Technological University.

13. Catalan, M., Impavido, G. and Musalem, A. (2000). Contractual Savings or Stock Market Development: Which Leads? Policy research Paper Nr.2421, World Bank, Washington. 
14. Ching, K., Kogid, M. and Furuoka,F. (2010). Causal relation between life insurance funds and economic growth: Evidence from Malaysia, ASEAN Economic Bulletin, August.

15. Crothers, A.G. (2004), Commercial Risk and Capital Formation in early America: Virginia Merchants and the Rise of American Marine Insurance, 1750-1815, Business History Review.

16. Ekpenyong, D. B. \& Acha, I. A. (2011). Banks and Economic Growth in Nigeria, European Journal of Business and Management, 3(4), 155-166. Available online at www.iiste.org/Journals/index.php/ EJBM/article/view/303

17. Eze, R. and Okoye V. (2013) Analysis of insurance practices and economic growth in Nigeria: using co-integration test and error correction model. Global Advanced Research Journals 2(1) 063-070.

18. Fatula, O. (2007). "The imperative of Recapitalisation and Consolidation in the Nigeria Insurance Industry" I (I\&II), Ikeja Bar Review, p. 128.

19. Haise P, Sümeg K (2008). "The relationship between Insurance and Economic Growth in Europe. A Theoretical and empirical analysis”. Empirical Journal, 35(4): 405-431.

20. Johansen, S. and Juselius, K. (1990) Maximum Likelihood Estimation and Inference on Cointegration- with Applications to the Demand for Money. Oxford Bulletin on Economics and Statistics. 52, $169-210$.

21. John, A. (1953), Insurance Investment and the London Market of the 18th Century Economica, 20 (78)137-158.

22. Johnson, O. (2008) Transformation and Insurance Growth in Nigeria. Accenture.

23. Kugler, M. and Ofoghi, R. (2005) Does Insurance Promote Economic Growth? Evidence from the UK.Journal of the American Association, 74: 427-431

24. MacMinn, R. (1987) Insurance and Corporate Risk Management, Journal of Risk and Insurance, 55 (4) 658-677.

25. Marijuana C, Sandra L, Lime P (2009). Insurance Sector development and Economic growth in Transition countries. International Resources Journal of Finance and Economics, 34.

26. Merton R. (2004). "Financial Innovation and Economic growth". Harvard China review. p. 5.

27. Merton R. and Bodie, Z. (1995). A Conceptual Framework for Analysing the Financial Environment. Eds. Crane et al DB The Global Financial System, a Functional Perspective, Harvard Business School press. pp. 3-31.

28. Obasi, M. (2010) Scale Economics and Performance Evaluation of Insurance Markets in Nigeria. Journal of the Social Sciences 4(1) 11-29.

29. Oke, M. (2012) Insurance Sector Development and Economic Growth in Nigeria. African Journal of Business Management 6(23), 7016-7023.

30. Okonkwo, O., Ogwuru, H. and Ajudua, E. (2014) Stock Market Performance and Economic Growth in Nigeria: An Empirical Appraisal. European Journal of Business and Management 6 (26) $33-42$. 
31. Okonkwo, O., Ogwuru, H. and Ajudua, E. (2014) Stock Market Performance and Economic Growth in Nigeria: An Empirical Appraisal. European Journal of Business and Management 6 (26) $33-42$.

32. Osunkunle, B. (2002). Impact of Insurance in Nigeria. Ibadan, Evans Brothers Publishers.

33. Peter R. and Kjell, S. (2006). The relationship of insurance and economic growth, A theoretical and Empirical analysis. A paper presented at the 2006 EcoMod Conference, Hongkong. June 2830.

34. Skipper, H. (2001) Insurance in the General Agreement on Trade in Services. American Enterprise Institute.

35. Taiwo, A. (2013) The Causal Relationship Between Insurance and Economic Growth in Nigeria (1986-2010) Australian Journal of Business and Management Research. 2(12): 49-57.

36. Wadlamannati K. (2008). "Do Insurance Sector Growth and Reforms affect Economic Development? Empirical Evidence from India". Journal of Applied Economic Resources, 2(1): 4386.

37. Ward, D. and Zurbruegg, R. (2000). Does Insurance Promote Economic Growth? Evidence from OECD Countries, Journal of Risk and Insurance, 67(4): 489-506. 